\title{
Environmental Concerns from the Page to the Screen: The Road and
}

\section{The Mist in Perspective}

\author{
Sakti Sekhar Dash \\ Fellow of Social Science Research Council \\ India \\ saktisekhardash96@gmail.com
}

Abstract

The publication of Rachel Carson's Silent Spring in 1962 triggered widespread concerns for the environment that eventually gave rise to environmental studies and ecocriticism. Writers of fiction presented frightening pictures- the result of the conflict between humans and the environment. Stephen King's novels like The Mist and The Stand were quick to point out the catastrophic consequences that awaited the human race. Another novelist who voiced his concerns for the environment was Cormac McCarthy. Almost a reclusive figure, McCarthy won the Pulitzer Prize for the novel, The Road. Stephen King's The Mist and Cormac McCarthy's The Road share striking similarities; both the novels present the human community coming to terms with an Eco-catastrophe. Both the novels got adapted into motion pictures, which showcased the issues and concerns raised by the novelists before a wider audience. The Mist was released in 2007 and The Road hit the screens a couple of years later. With the release of the motion pictures, environmental concerns raised by Rachel Carson in Silent Spring and furthered by King and McCarthy had successfully made a foray into the world of digital media. During the latter stages of the $20^{\text {th }}$ century, environmental concerns and studies had remained confined to print media, demonstrations, agitations and pamphleteering. With the publication of the novels like The Mist and The Road environmental concerns and issues gained mass appeal. This culminated with the release of 
the motion pictures, which managed to garner critical acclaim and presented before a diverse audience, the issues plaguing the human-nature relationship.

Keywords: Ecology, Scientific Hubris, Eco-catastrophe, Eco-monstrous, Post-apocalyptic Introduction

On $27^{\text {th }}$ September, 1962, Rachel Carson's Silent Spring was published. It created an unprecedented stir in the fields of literature and environmental conservation. The United States stood divided over Carson's work; while many called for a sustainable relationship between the human community and the ecology, there were others who were keen to go ahead with radical methods to further human interests, without taking into consideration the damages caused to the environment. In Silent Spring, Carson has documented the disastrous effects of chemicals, pesticides and insecticides in the agriculture industry. To boost the crop yield, humans have adopted scientific methods without taking into account the adverse effects caused in the long run. Carson furthered her arguments regarding the disastrous consequences of pesticides and rightfully called them "biocides". In particular, she critiqued the use of DDT for the toll it took on avian populations. Furthermore, she highlighted DDT's carcinogenic characteristics. Carson argued that scientific thinking and progress came at a cost; technological advancements were responsible for subverting and controlling the natural world. Carson's response was against the human efforts to control nature through artificial means. She pointed out the adverse effects on the ecology through the human actions in Silent Spring.

Carson's work triggered wide spread concerns not just in the United States, but also in other countries. People hit the streets protesting against the use of pesticides and insecticides. Environmental studies gained newfound momentum as critics like Carolyn Merchant, Cheryl Glotfelty, William Reuckert began to explore the complex and diverse relationship between humans and the ecology through the lens of literature. Fictional literature did not lag far 
behind in portraying the issues plaguing the human-nature relationship. Writers did not turn a blind eye to the human efforts and attempts to control non-human nature through scientific means. The works that hogged the limelight include The Drowned World by J. G. Ballard, The Overstory by Richard Powers, Gold Fame Citrus by Claire Watkins, and Oryx and Crake by Margaret Atwood. A recurring motif in these works is the role of science in undermining the human-nature relationship. Science acts as a double-edged sword that undermines the ecology of which humans are an integral part.

Two novels stand out for their depiction of the post-apocalyptic scenario that emerges due to the unbridled use of scientific technology. These are The Mist by Stephen King and The Road by Cormac McCarthy. The novels presented frightening portraits of the human civilization caught in the maelstrom of an eco-catastrophe. The humans are confronted by an ecology that seems altogether strange and alien. But the issues that trigger the ecological catastrophe are merely hinted at by the novelists. The ambiguity of the events that precipitate the calamities only amplifies the magnitude of the disasters.

The Mist: Mists, Monsters and the Eco-monstrous

In 1980, The Mist by Stephen King was published to critical acclaim. Though it fell into the genre of horror fiction, yet the ecological undertones could scarcely be ignored. In the small town of Bridgeton in Maine, the people experience a cataclysmic thunderstorm. But the storm is only the tip of the iceberg. After the squall, the humans are baffled by the mist that engulfs everything. But they are quick enough to realise that it is no ordinary mist; it hides unnameable horrors that appear to have emerged out of the worst nightmares. Trapped in a supermarket, the humans are preyed on by nameless creatures from the mist:

Things began to happen at an accelerating, confusing pace then. A man staggered into the market, shoving the INdoor open. His nose was bleeding. "Something in the fog! "he screamed, and Billy shrank against me-whether because of the man's bloody 
nose or what he was saying, Idon't know. "Something in the fog! Something in the fog took John Lee! Something__" He staggered back against a display of lawn food stacked by the window and sat down there. "Something in the fog took John Lee and I heard him screaming!'”(The Mist,p.78)

King reminds the readers of the hypnotic power of nature, before which the human agencies appear helpless. In the words of King:

There are big forces in nature that you hardly ever see-earthquakes, hurricanes, tornadoes-I haven't seen them all but I've seen enough to guess that they all move with that lazy, hypnotizing speed. (The Mist,p.81)

Several characters become the victims of the creatures. Norm the bag boy is one of the earliest victims- he is dragged off by monstrous tentacles. But, the characters never learn about the creature to whom the tentacles belong. The identity and the origins of the monstrous creatures remain as hazy and obscure as the mist that has engulfed the town, and in all probability, the rest of the country.

His hand was gripping my arm hard. "All right," he said."Yes, I just keep asking myself . . . all those tentacles ... like a squid or something ... David, what were they hooked to? What were those tentacles hooked to?" (The Mist,p.108)

Trapped in the supermarket, a few people led by Brent Norton try to escape. But their bid fails and they are brutally killed by the unseen creatures. Mingled with their dying screams, are the roars and grunts of the monstrous creatures from the mist.

It was like no sound I've ever heard, but the closest approximation might be a movie set in the African veld or a South American swamp. It was the sound of a big animal. It came again, low and tearing and savage. Once more ....and then it subsided to a series of low mutterings. (The Mist, p. 144) 
When the creatures reveal themselves to the humans inside the supermarket, they evoke a mixture of fear and disgust. Plainly, these creatures that make an appearance are not the ones that claimed the lives of Norm, Brent and the others. They appear to be strangely mutated forms of familiar insects.

It was maybe two feet long, segmented, the pinkish color of burned flesh that has healed over. Bulbous eyes peered in two different directions at once from the ends of short, limber stalks. It clung to the window on fat sucker-pads. From the opposite end there protruded something that was either a sexual organ or a stinger. And from its back there sprouted oversized, membranous wings, like the wings of a housefly. (The Mist 150)

The insects are eaten by winged creatures that appear to be hideous caricatures of birds. In fact, the events that unfold appear to be a grotesque parody of the events occurring in the natural world. Insects get eaten by birds- but they are no ordinary insects and the birds seem otherworldly to say the least. King adds:

The fog appeared to darken in exactly the way Ollie had described, only the dark smutch didn't fade away; it solidified into something with flapping, leathery wings, an albino-white body, and reddish eyes. It thudded into the glass hard enough to make it shiver. Its beak opened. It scooped the pink thing in and was gone. (The Mist, p.152) Encountering familiar life forms metamorphosed into monstrous and dreadful forms unhinges the minds of the people. As hope runs out and despair consumes them, they make a last-ditch effort to save themselves by venturing out of the supermarket, looking for the means to escape. But they only manage to encounter more mutated life forms in the guise of killer spiders.

One of the spiders had come out of the mist from behind us. It was the size of a big dog. It was black with yellow piping. Racing stripes, I thought crazily. Its eyes were 
reddish-purple, like pomegranates. It strutted busily towardus on what might have been as many as twelve or fourteen many-jointed legs - it was no ordinary earthly spider blown up to horror-movie size; it was something totally different, perhaps not really a spider at all. (The Mist, p.191)

In the concluding pages of the novel, the survivors encounter monstrous creatures that a rational mind could scarcely conceive. In vivid detail King writes:

It was six-legged, I know that; its skin was slaty gray that mottled to dark brown in places. Those brown patches reminded me absurdly of the liver spots on Mrs. Carmody's hands. Its skin was deeply wrinkled and grooved, and clinging to it were scores, hundreds, of those pinkish "bugs" with the stalk-eyes. I don't know how big it actually was, butit passed directly over us. One of its gray, wrinkled legs smashed down right beside my window, and Mrs. Reppler said later she could not see the underside of its body, although she craned her neck up to look. She saw only two Cyclopean legs going up and up into the mist like living towers until they were lost to sight. (The Mist, p.219)

The novel leaves many questions unanswered. The chief one that raises its head is, "What led to the birth of the eco-monstrous?" Perhaps, the answers can be found in the cryptic words"Arrowhead Project". Time and again it surfaces during conversations and in the mind of David Drayton. Two soldiers who were a part of the Arrowhead Project commit suicide by hanging themselves in the supermarket. This leads Ollie Weekes to speculate about the true nature of Arrowhead Project.

Ollie said, "I stand by one of those registers all day long and I hear a lot. All this spring I've been hearing things about that damned Arrowhead thing, none of it good. The black ice on the lakes_-" (The Mist, p.166) 
It is evident that the Arrowhead Project involved scientific experimentation. As Bill Giosti speculates, they could have been messing with atoms. Even Weekes felt the same:

They could have been fooling around with anything. Some people claim they were messing with high intensity lasers and masers. Sometimes I hear fusion power. And suppose ... suppose they ripped a hole straight through into another dimension?" (The Mist, p.168)

Despite the ambiguity surrounding the Arrowhead Project, it is quite apparent that it is responsible for the creation of a monstrous ecology. Human agencies had been tinkering with the natural world, using scientific means to control the ecology. But the disastrous consequences resulting from the experimentation, makes the human community the biggest victim.

The Road: No Hope in Sight

The Road for which Cormac McCarthy won the Pulitzer Prize presents an unflattering picture of the American landscape. It is a cold gray world, with hardly any vestiges of human civilisation. An unspecified disaster has turned the country into a cold and dead wasteland. As Erik Hage adds:

For a father and son trudging day by day through a barren, scorched landscape of gray, endlessly foraging in wasted buildings for food and supplies—while trying to avoid rogue tribes of cannibals - there is only good and evil, survival, and God, whom the father sometimes addresses in desperation and anger, lifting his face to the heavens: "Areyou there? he whispered. Will I see you at last? Have you a neck by which to throttle you? Damn you eternally have you a soul? Oh God, he whispered. Oh, God" (pp. 11-12). (Critical Companion to Cormac McCarthy, p.140)

McCarthy presents a post-apocalyptic world, where the surviving humans have to confront an ecology that has entered into a catatonic state. The landscape wears a bleak look, covered 
with ashes. The surviving humans have been divided into two distinct groups- "the good guys" and "the bad guys". The bad guys are the cannibals, who prey on the "good guys". Following the collapse of the civilisation and the ecology, law, order and moral values have ceased to exist.

As the father-son duo make their way across the barren landscape, not only do they have to survive the harsh conditions, but also save themselves from the prowling groups of cannibals. The Road follows a post-apocalyptic narrative and Cormac McCarthy eschews punctuation elements. This eerily coincides with the new world that has emerged, where the vestiges of the old world are absent. The father-son duo comes across towns and cities without electricity, water and human inhabitants. The new world that has emerged following the catastrophe serves to remind the survivors of the magnitude of the loss incurred by the human race. Empty houses, wrecked billboards and dilapidated hotels remind the survivors of the human race's aspirations and the present state is little more than a skeletal remnant of the past. Like the bones dotting the landscape, human civilisation has decayed and crumbled into nothingness. McCarthy writes:

The town had been abandoned years ago but they walked the littered streets carefully, the boy holding on to his hand. They passed a metal trash dump where someone had once tried to burn bodies. The charred meat and bones under the damp ash might have been anonymous save for the shapes of the skulls. No longer any smell. (The Road, p.105)

Cormac McCarthy's novel is set in a post-apocalyptic world, but the novelist never mentions explicitly the cause of the disaster. The Road has often been cited by environmentalists as a grim and ominous warning; an ecological disaster is inevitable if the human community fails to address the issues of climate change, pollution and environmental exploitation. On account of the disaster, a large number of humans have also perished along with the non-human 
species. Death and darkness are eternally present elements in the novel, embodied by the cold, gray landscape, absence of light, and the landscape covered with ashes. Adapting to this post-apocalyptic world is no mean feat and the woman chooses to commit suicide rather than risk capture by the cannibalistic groups. By doing so, she takes death as her "new lover".

A disaster of cataclysmic proportions has wiped out the ecology and irrevocably ruined the human civilisation. The unnamed disaster that affects humanity has been hinted at by McCarthy:

The clocks stopped at 1:17. A long shear of light and then a series of low concussions. He got up and went to the window. What is it? she said. He didn't answer. He went into thebathroom and threw the lightswitch but the power was already gone. A dull rose glow in the window glass. (The Road, p.37)

The nature of the disaster recounted by McCarthy seems eerily similar to the nuclear catastrophe that destroyed Chernobyl. Widely regarded as the worst nuclear disaster in history, the nuclear catastrophe caused unimaginable losses to the Soviet Union and turned the town of Pripyat into a ghost town.

On $26^{\text {th }}$ April, 1986 a test was being carried out which got out of hand and led to an uncontrolled nuclear reaction. The energy released led to an explosion and spread nuclear dust across the region. The exact number of deaths has never been ascertained. The effects of the nuclear catastrophe took their toll on the ecology as well. It led to mutations among the wild life and made the place inhospitable for human habitation.

Something similar has transpired in The Road. The disaster has caused the land to become inhospitable for human habitations; non-human life forms have also suffered the disastrous consequences of the catastrophe. In the bleak and devastated landscape, the few surviving humans must struggle ceaselessly to avoid extinction.

Scientific Hubris 
In The Mist and The Road human agencies were tampering with scientific technology that caused eco-catastrophes. The Arrowhead Project and the unnamed disaster led to situations that affect the human community the most. Critics "have called The Road an ecological tragedy, a warning about humankind's hubristic refusal to care adequately or our environment" (Pebbles 97). The same goes for Stephen King's The Mist. Through scientific means, the human community has tried to assume control of non-human nature and the ecology. But in the process, undermines the delicate balance between the ecology and the human community.

In Greek myths, literature and philosophy, hubris finds frequent mention. It has been generally regarded as the pride, arrogance and over-confidence that causes the individual's downfall. In the wake of the Renaissance and Enlightenment, scientific hubris came into existence. With a growing sense of anthropocentrism, humans began to turn to scientific means and methods to further their interests. In the process, they stopped caring about the ecology and non-human nature. Science simplified human life and opened up new vistas whereby the human community could harness the very forces of nature. This granted the humans unbridled power over the ecology. As humans went ahead with their designs to control the environment, ecology and the nature, they slowly alienated themselves from their environment. Arrogance and pride resulting from their scientific achievements fuelled their hubris, as the human community stopped at nothing to achieve its desired objectives. The scientific hubris has been responsible for the treatment of the environment as the 'other' and the destruction of the ecology. Scientific thinking and anthropocentrism took an objective stance and sanctioned the exploitation of the ecology for human gains.

The rupture in the ecological balance leads to the creation of the eco-monstrous in The Mist and precipitates the eco-catastrophe in The Road that has marked the death of the human civilisation. In his efforts to seize control of the ecology and the world, man has only 
managed to alienate himself from non-human nature and this births a vicious cycle of violent ecological disasters that spares no one.

In Silent Spring, Rachel Carson had gone to great lengths to illustrate the precarious nature of the ecological crisis. On account of its scientific hubris, the human race has sought to subjugate and harness the forces of nature for their own ends. In the process, they have irrevocably ruined the ecology, without realising the fact that they are an integral part of the environment. The ecological disasters and catastrophes occurring as a result of irresponsible and indiscriminate manipulation of the environment is likely to affect the humans as much as the non-human life forms, if not more.

From the Page to the Screen

Directed by Frank Darabont, The Mist was released as a motion picture in 2007. It brought to the screen the very concerns and horrors highlighted by Stephen King in The Mist. As in the novel, the Arrowhead Project is a looming presence in the background. It sufficiently illustrates the damage caused by man's scientific hubris. In Michael Crichton's Jurassic Park, Ian Malcolm succinctly sums up the hazards posed by scientific hubris:

Scientists are actually preoccupied with accomplishment. So they are focused on whether they can do something. They never stop to ask ifthey should do something. They conveniently define such considerations as pointless. If they don't do it, someone else will. Discovery, they believe, is inevitable. So they just try to do it first. That's the game in science. Even pure scientific discovery is an aggressive, penetrative act. It takes big equipment, and it literally changes the world afterward. Particle accelerators scar the land, and leave radioactive by-products. Astronauts leave trash on the moon. There is always some proof that scientists were there, making their 
discoveries. Discovery is always a rape of the natural world. Always. (Jurassic Park, pp.430-431)

The Mist paints a grim picture of a devastated world; but the most disturbing fact is- the devastation has been wrought by human agencies. The scientists and soldiers involved in the Arrowhead Project have caused an ecological catastrophe that endangers the lives of many and kills many more. Undoubtedly, science has simplified human existence; enabled the human race to achieve the unthinkable. But at the same time, it has infused pride and hubris among the humans who take the ecology and the environment for granted. They simply perceive it as a warehouse of resources designed for human use. Science becomes a tool in the exploitation and destruction of the ecology. In his harsh criticism of science, Ian Malcolm adds:

But science cannot help us decide what to do with that world, or how to live. Science can make a nuclear reactor, but it cannot tell us not to build it. Science can make pesticide, but cannot tell us not to use it. Andour world starts to seem polluted in fundamental ways - air, and water,and land-because of ungovernable science. (Jurassic Park, pp.471-472)

The horrifying consequences of man's scientific hubris has been remarkably presented in The Road directed by John Hillcoat. Portraying a desiccated world, The Road brings to the screen the vision of the human race's final days. In the words of Willard P. greenwood:

The Road's central conflict is that an unnamed disaster-in all probability a nuclear holocaust-has created a nuclear winter on earth. The story is set in America where all traces of modern society have stopped functioning. There is no electricity; there is no gasoline; there are no factories or stores or automobiles. Anarchy reigns in this desolate ash covered world where the sun has been blotted from the sky. (Reading Cormac McCarthy, p.77) 
The father-son duo makes their way across the bleak and barren wasteland, foraging for supplies and saving themselves from the cannibals. The Road certainly drives home the fact that the days of the human race are numbered.

\section{Conclusion}

In Silent Spring, Rachel Carson had voiced her worst fears stemming from the human race's hubristic exploitation and manipulation of the environment. Carson minces no words in stating the root of the problem; man, comfortably ignores the fact that he is a part of the ecology. Speciesism and anthropocentrism have created a divide between the human race and non-human nature. Treating the ecology as the 'other' man has tried every possible means to further his own interests at the expense of the environment. Through the indiscriminate use of pesticides, the crop yields have grown by leaps and bounds. But Carson brings to the forefront- the uncomfortable truth concerning the toll on the environment taken by the pesticides and insecticides. The environmental concerns voiced by Carson triggered various movements calling for environmental conservation and sustainable use of resources. But the movements and agitations would have fizzled out, had it not been for the works of fiction that presented the horrors of a ruined ecology before the populace. The Mist and The Road successfully drove home the truth that man himself would be the biggest victim of the ecological disasters. Due to scientific hubris and an apathy towards the environment, the human race had been steadily ruining the delicate ecological balance. The works got adapted into motion pictures, which carried forth the environmental concerns from the page to the screen. 


\section{Works Cited}

Carson, Rachel. Silent Spring. Mariner Books Houghton Mifflin Harcourt, 2002.

Crichton, Michael. Jurassic Park. Ballantine Books, 2015.

Greenwood, Willard P. Reading Cormac McCarthy. Greenwood Press, 2009.

Hage, Erik. Cormac McCarthy: A Literary Companion. McFarland \& Company, 2010.

King Stephen. The Mist. Signet, 1986.

McCarthy, Cormac. The Road. Picador, 2006. 